THE production of acute phase cytokines, in terleukin 6 (IL-6), tumour necrosis factor (TNFo) and interleukin 1 (IL-1 $\beta$ ), was studied in primary cultures of human skin fibroblasts, human monocytic cell line U937 and primary cultures of human umbilical vein endoth elial cells (HUVEC) after in vitro in fection with vaccinia virus. Significant increase in IL-6 mRNA followed by enhanced protein secretion in to the culture media was found in fibroblasts, U937 cells, and HUVEC. TNF $\alpha$ increased production in vaccinia virus infected U937 cells resembled closely the pattern of IL-6 production observed in the in fected cells. Transient increase in NF- $\kappa B$ binding activity was found in the in fected U937 (at $90 \mathrm{~m}$ in) and endothelial (at $30 \mathrm{~min}$ ) cells. Vaccinia virus induced cytokine production appeared to be transcriptional.

Key words: Vaccinia virus, Acute phase cytokines, Fibroblasts, U937, HUVEC

\section{Vaccinia virus-regulated acute phase cytokine production in human fibroblasts, U937 cells and endothelium}

\author{
H. Rokita, ${ }^{\text {CA }}$ T. Kupiec, ${ }^{*}$ K. Guzik and A. Koj
}

Institute of Molecular Biology, Jagiellonian University; 3, Mickiewicza Av.; 31-120 Kraków, Poland *Present address: Institute of Forensic Research; 9, Westerplatte Str.; 31-033 Kraków, Poland

\author{
${ }^{\mathrm{CA}}$ Corresponding Author \\ Tel: $(+48) 126341442$ \\ Fax: $(+48) 126336907$
}

\section{Introduction}

Vaccinia virus (V) belongs to the poxviruses superfamily, a group of large DNA viruses known from their exclusive propagation within the cytoplasm of eukaryotic cells. WV infections are commonly associated with a generalized host cell protein and nucleic acids synthesis inhibition. The shut down of host transcriptional and translational machineries is done in favour of selective expression of viral genes. ${ }^{1,2}$ However, several groups of eukaryotic proteins are transiently induced by many viruses in infected cells, e.g. cytokines (TNF $\alpha$, IL-6, INF $\gamma$ ), ${ }^{3,4}$ heat shock proteins (mouse hsp72) ${ }^{5}$ and transcription factors (NF-kB). ${ }^{6}$

Viral infections are accompanied by dysregulation of cytokine production and virus-cytokines interactions appear to be complex as cytokines by themselves possess pleiotropic activities. Induction of a cytokine, a cytokine receptor or a growth factor production by a virus could stimulate its own replication and infectious virus production (like IL-8 for HCMV). ${ }^{7}$ Some cytokines might also help to escape immune responses if a cytokine exerts a negative effect on the immune system (like EpsteinBarr virus encoded IL-10, typical antiinflammatory cytokine). ${ }^{8}$ Therefore, reduction of proinflammatory cytokines production, like IL-1 and TNF $\alpha$, having not only direct antiviral effect (like TNFa) but also coordinating the host inflammatory and immune responses to viral infection, could lead to viral infection progression. ${ }^{9}$
DNA viruses like vaccinia and other orthopoxviruses, possessing large genomes, acquired anticytokine defense mechanisms encompassing expression of soluble cytokine receptor genes and cytokine converting enzymes. ${ }^{10}$ Thus, virus encoded several cytokine response modifiers (like crm A) act together to inhibit the release of proinflammatory cytokines in response to infection. ${ }^{11}$

To further understand the biology of vaccinia virus and virally induced acute phase response, acute phase inflammatory cytokines were measured in three infected human cell types: primary cultures of skin fibroblasts, the promonocytic cell line U937 and umbilical vein endothelial cells.

\section{Materials and Methods}

\section{Cells and viruses}

The WR strain of vaccinia virus was propagated on Vero cells infected at multiplicity of infection (MOI) 1:1 (one plague forming unit per cell), maintained in MEM supplemented with $4 \%$ heat-inactivated FCS. Infected cells were harvested at maximum cytopathic effect and infectivity estimated by quantal infectivity assay on Vero cells. ${ }^{12}$

Human skin fibroblasts were cultured in MEM containing $10 \%$ FCS, $2 \mathrm{mM}$ glutamine and antibioticantimycotic mixture (passage 3-12 was used). For RNA extraction cells were grown in $84 \mathrm{~mm}$ diameter culture dishes in the density of $1.8 \times 10^{6}$ cells/dish in 
MEM with 5\% FCS. As a positive control of cytokine production, LPS (lipopolysaccharide from Escherichia coli $026: \mathrm{B} 6$, Sigma) in concentration $1 \mu \mathrm{g} / \mathrm{ml}$ and IL-1 $\alpha(10 \mathrm{ng} / \mathrm{ml})$ were used.

U937 cells were grow $n$ in RPMI supplemented with $8 \%$ FCS and antibiotics. The experiments were carried out on U937 cells differentiated into a macrophagelike cells in the presence of $50 \mathrm{nM}$ phorbol myristate acetate (PMA) for 24-36 h. Adherent cells (in RPM with $4 \%$ FCS without PMA) were infected or treated with LPS for an additional 6-24h.

Endothelial cells were isolated from human umbilical cord veins. Umbilical veins from individual cords were cannulated, washed with HBSS without $\mathrm{Ca}$ and $\mathrm{Mg}$ and filled with $0.1 \%$ collagenase type I in HBSS with $\mathrm{Ca}$ and $\mathrm{Mg}$. After a 15 -min incubation at $37^{\circ} \mathrm{C}$, the detached cells were collected and washed by three times repeated centrifugation and resuspended in M199 containing 20\% heat-inactivated FCS, heparin $(10 \mathrm{U} / \mathrm{ml})$, HEPES $(15 \mathrm{mM}), 1 \%$ gentamycin and endothelial cell growth supplement (ECGS) $(50 \mu \mathrm{g} / \mathrm{ml})$. Cells from passages 2 to 4 were grown on $5 \%$ gelatinprecoated $60-\mathrm{mm}$ culture dishes.

All cultures were infected with vaccinia virus at MOI 1:1, 2:1 or 4:1 (as indicated in the figure legends) at the time of LPS addition. Mock infected (control) cultures were prepared in the same way. Infected cells were washed after 1 h virus adsorption and fresh medium added. Effectiveness of infection was routinely checked by microscopic examination at $24 \mathrm{~h}$ postinfection (p.i.) and typical rounding of infected cells was observed. Higher infectious doses than the doses used would result in profound cytopathic effect at $24-48 \mathrm{~h}$.

The viability of the cells was routinely checked using fluorescein diacetate/ethidium bromide double fluorescent test.

\section{Cytokine assay}

TNF $\alpha$, IL-1 $\beta$ and IL- 6 proteins were determined in culture media using commercially available ELISA kits (Genzyme).

Statistical significance of the differences between means was estimated using Fisher-Behrens test.

\section{RNA extraction and northern blot analysis}

Total RNA was extracted from cultured cells using standard phenol-chloroform method and $\mathrm{LiCl}$ precipitation. ${ }^{13}$ RNA samples $(10 \mu \mathrm{g})$ were separated electrophoretically in $1 \%$ agarose gel under denaturing conditions. ${ }^{14}$ RNA was then transferred to hybond-N membranes (Amersham, UK). The blots were baked at $80^{\circ} \mathrm{C}$ for $2 \mathrm{~h}$ and prehybridized $1-3 \mathrm{~h}$. Specific mRNAs were detected by hybridization at $68^{\circ} \mathrm{C}$ in $10 \%$ dextran sulfate, $1 \mathrm{M} \mathrm{NaCl}$ and $1 \%$ SDS with $1.2 \mathrm{~kb}$ Eco RI-Hindlll fragment of human IL-6 cDNA (kindly donated by Dr T. Kishimoto), or $1.1 \mathrm{~kb}$ Pstl fragment of human TNFa (ATCC, Rockville, MD) labelled with ${ }^{32} \mathrm{P}-\mathrm{dCTP}$ by random priming.

\section{Reverse transcriptase-PCR}

cDNA synthesis reactions were done in a total volume of $20 \mu \mathrm{l}$ containing $10 \mu \mathrm{l}$ of each RNA sample $(0.5$ or $1 \mu \mathrm{g}), 0.5 \mu \mathrm{g}$ oligo $(\mathrm{dT})_{12-18}$ primer (Gibco) and $200 \mathrm{U}$ of SuperScript ${ }^{\mathrm{TM}}$ ll RNAse H-Reverse Transcriptase (Gibco) according to the protocol provided with the enzyme. PCRs were set up in a total volume of $50 \mu \mathrm{l}$ containing $5 \mu \mathrm{l}$ of the cDNA, $0.2 \mathrm{mM}$ deoxynucleoside triphosphate, $0.5 \mu \mathrm{M}$ of each oligonucleotide primer, $50 \mathrm{mM} \mathrm{KCI}, 1.5 \mathrm{mM} \mathrm{MgCl}_{2}$, and $2.5 \mathrm{U}$ of Taq polymerase (Gibco). PCRs were run on $0.5 \mathrm{ml}$ tubes, in OmniGene thermal cycler (Hybaid, Teddington, UK) equipped with heated lid. Reactions were carried out at the following conditions: $94^{\circ} \mathrm{C}$ for $1 \mathrm{~min}, 60^{\circ} \mathrm{C}$ for $1 \mathrm{~min}$, and $72^{\circ} \mathrm{C}$ for $1.5 \mathrm{~min}$. for 35 cycles (IL-6, TNF- $\alpha$ ), or $94^{\circ} \mathrm{C}$ for $1 \mathrm{~min}, 55^{\circ} \mathrm{C}$ for $1 \mathrm{~min}$, and $72^{\circ} \mathrm{C}$ for $1.5 \mathrm{~min}$ for 35 cycles ( $\beta$-actin). Each thermal profile was ended with final extension at $72^{\circ} \mathrm{C}$ for $10 \mathrm{~min}$. The reaction products were then resolved on nondenaturing $2 \%$ agarose (Sigma, St Louis, MO) gel and visualized by staining with ethidium bromide.

The following PCR primers were custom-synthesized by Gibco:

\section{TNF $\alpha$ (sense) \\ 5'-ATGAGCACTGAAAGCATGATC-3'; \\ (anti) \\ 5'-GCAATGATCCCAAAGTAGACCTGCCC-3';}

IL-6 (sense)

5'-CTTTTGGAGTTTGAGGTATACCTAG-3';

(anti)

5'-GCTGCGCAGAATGAGATGAGTTGTC-3';

$\beta$-actin (sense)

5'-AGCGGGAAATCGTGCGTG-3';

(anti)

5'-GGGTACATGGTGGTGCCG-3' .

All primers were designed to match sequences in separate exons to avoid the contribution of genome templated product in the analysed signal. The expected product lengths are: $702 \mathrm{bp}$ for TNF $\alpha, 237 \mathrm{bp}$ for IL-6 and 307bp for $\beta$-actin.

\section{Electrophoretic mobility shift assay}

Nuclear extracts were prepared from vaccinia virus infected U937 cells and HUVEC by using the method of Suzuki et al. ${ }^{15}$ Protein concentrations were determined by bicinchoninic method (Sigma) according to manufacturer's instruction. 
DNA mobility shift assay was carried out as described by Duyao et al. ${ }^{16}$ A double stranded oligonucleotide 5'-AAGTCCGGGTTTTCCCCAACC-3' containing two repeats of $\mathrm{NF} k \mathrm{~B}$ binding site, corresponding to -1101 to $-1081 \mathrm{bp}$ region of murine c-myc ${ }^{16}$ was synthesized by Molecular and Macromolecular Research Center, Lódź, Poland. The DNA probe was end-labelled by using polynucleotide kinase and $\gamma-{ }^{32}$ P-ATP. Equal amounts of protein $(5 \mu \mathrm{g})$ in $10 \%$ glycerol were incubated at room temperature for $30 \mathrm{~min}$ with $0.5 \mathrm{ng}\left(-10^{5} \mathrm{cpm}\right)$ of the labelled dsDNA oligonucleotide in the presence of $4 \mu \mathrm{g}$ of poly (dl-dC) in $10 \mathrm{mMTris} \mathrm{pH} 7.5,50 \mathrm{mM} \mathrm{NaCl}, 1 \mathrm{mM}$ EDTA and $0.1 \mathrm{mM}$ DTT in a total volume of $25 \mu \mathrm{l}$. Some samples were incubated in the presence of 100 -fold molar excess of specific cold oligonucleotide probe as a competitor. Incubation mixtures were electrophoresed on $4.5 \%$ non-denaturing polyacrylamide gel in $0.5 \times \mathrm{TBE}$. The dried gels were analysed by autoradiography.

\section{Results}

Vaccinia virus infection induces transcription and secretion of IL-6 in human fibroblasts

Supernatants of infected human skin fibroblasts and uninfected control fibroblasts were collected and IL-6
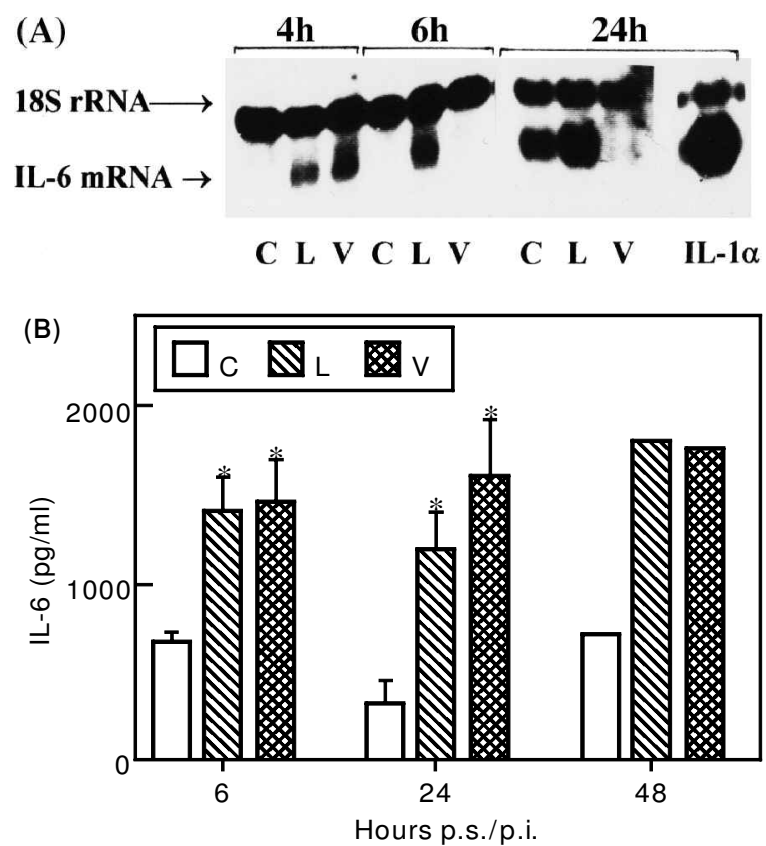

FIG. 1. IL-6 gene expression in vaccinia virus-infected human skin fibroblasts. Human skin fibroblasts remained either untreated (control-C), or were infected with vaccinia virus (V) (at MOI 2:1) or treated with LPS (L). After 4,6 or $24 \mathrm{~h}$ the cells were harvested for RNA extraction. $10 \mu \mathrm{g}$ of total RNA was applied per lane for Northern blot analysis with IL-6 specific cDNA probe (A). IL-6 protein was determined by ELISA in culture media from four separate experiments $(6$ and $24 \mathrm{~h}$ ) and a single experiment (48h) (B). Results are expressed as the mean \pm standard deviation. Statistically significant results and $\boldsymbol{P}$ values $<0.01$ are marked by* . measured by EUSA, while the cells were used for total RNA extraction. The representative experiment illustrated in Fig. 1A shows that vaccinia virus induced IL6 mRNA was detected only early post-infection (at $4 \mathrm{~h}$ ) and the transcript is not found after $6-48 \mathrm{~h}$ p.i. Despite this early message degradation, IL- 6 protein was detected in the culture media at all times p.i. and even at $48 \mathrm{~h}$ the cytokine was further increased by the virus (Fig. 1B). Quantification of IL-6 showed that amounts of IL-6 induced by LPS and lower doses of $\mathrm{VV}$ (MOI of $1: 1$ and 2:1) were comparable, however much higher infectious dose (MOI of 4:1) caused larger increase in cytokine production than after LPS addition (Fig. 2A). While primary cultures of human skin fibroblasts failed to produce detectable amounts of TNF $\alpha$, IL-1 $\beta$ was induced by LPS and VV as well as by combination of LPS and VV (Fig. 2B). No basal IL-1 $\beta$ expression level was found in control cultures. Almost synergistic effect of the combination of stimulants was found only for IL-1 $\beta$ (Fig. 2B), since IL-6 induction was not further induced by LPS and VV (Fig. 2A).
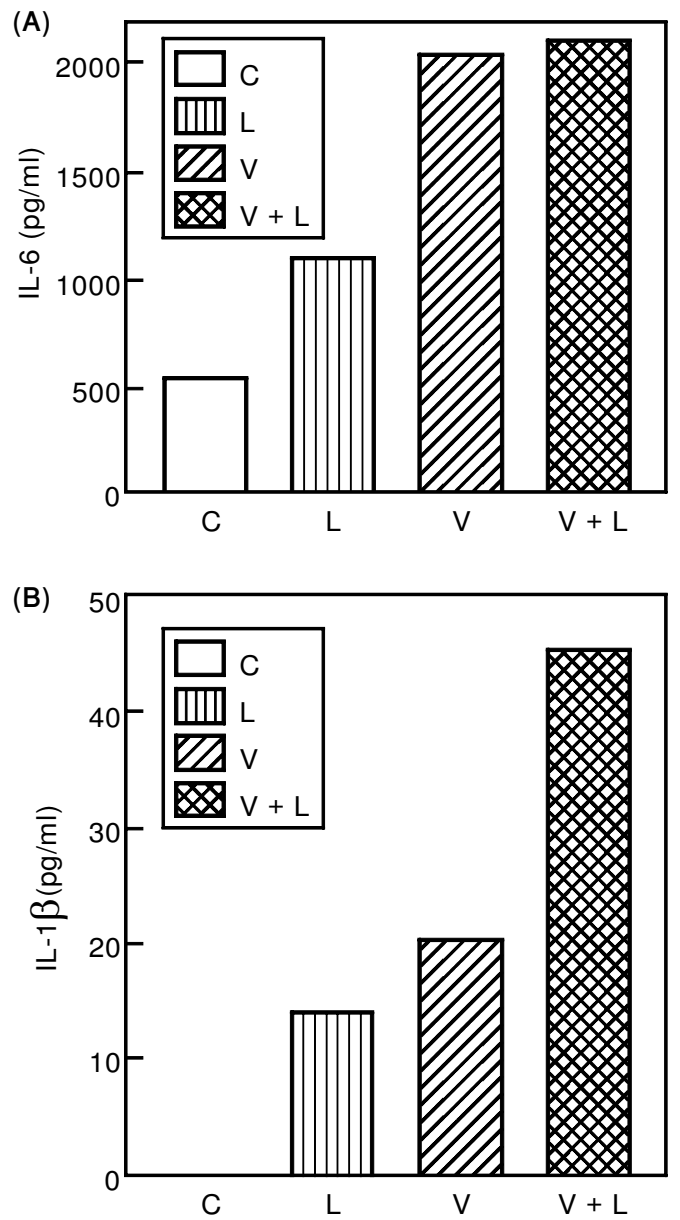

FIG. 2. Vaccinia virus and LPS effects on $I L-6$ and $I L-1 \beta$ secretion from human skin fibroblasts. IL-6 (A) and IL-1 $\beta$ (B) secretion was evaluated by ELISA in control $(C)$, vaccinia virus infected (V-at $\mathrm{MOI} 4: 1$ ) and/or LPS treated (L) human skin fibroblasts at $24 \mathrm{~h}$. The results come from a single experiment. 
(A)

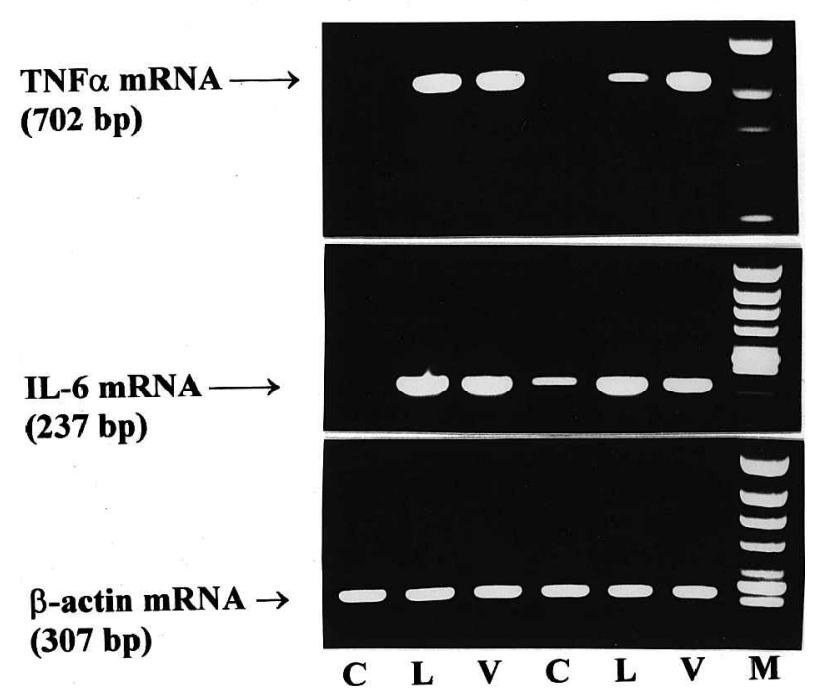

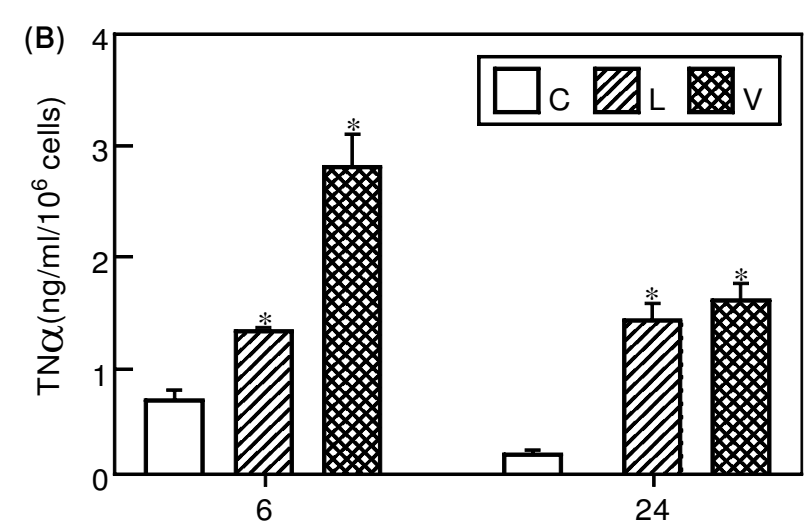

Hours p.i./p.s.

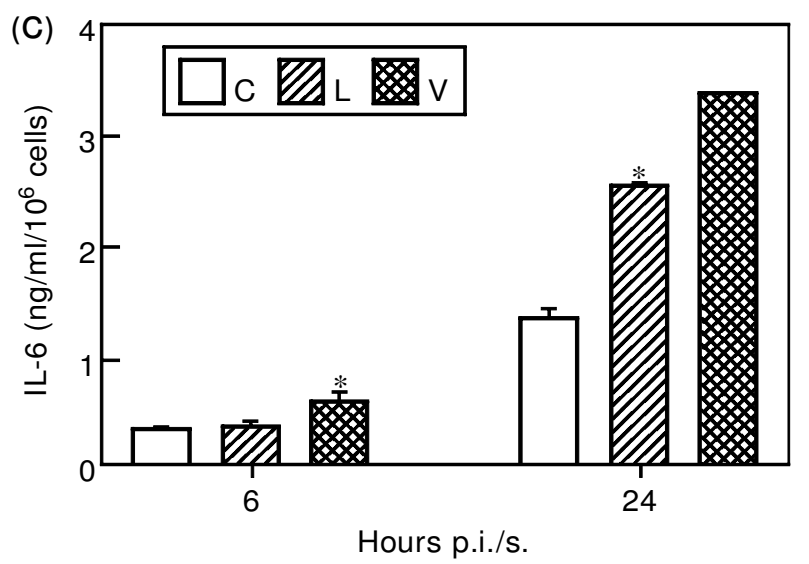

FIG. 3. Changes in TNF $\alpha$ and IL-6 gene expression in vaccinia virus infected U937 cells. TNF $\alpha$, IL-6 and $\beta$-actin mRNAs were measured by RT-PCR (A) and the cytokines secretion determined by ELISA (TNF $\alpha-B ;$ IL-6-C). RT-PCR data come from a single representative experiment, whereas cytokine proteins were analysed in culture media from three experiments and standard deviation shown where it was possible. Vaccinia virus infection was at $\mathrm{MOI}$ 1:1. C-control cultures, V-vaccinia virus infected cultures, L-LPS-treated cultures (performed as a positive control). Results are expressed as the mean \pm standard deviation. Statistically significant results and $P$ values $<0.01$ are marked by*
Vaccinia virus infected human monocytic cell line U937 produces increased TNF $\alpha$ and IL-6

PMA differentiated U937 cells produced increasing amounts of TNF $\alpha$ and IL- 6 mRNAs as well as the proteins as estimated by RT-PCR and ELISA (Fig. 3A,B, C). The cytokine was not detectable in fibroblast and HUVEC cultures. Although IL-6 accumulation was still enhanced at $24 \mathrm{~h}$, the cytokine transcripts were already decreased probably due to destability of the mRNA by the virus. Increased IL- 6 mRNA content found in $24 \mathrm{~h}$ control cultures seems to result from the culture conditions. Similar changes were observed in case of IL-1 $\beta$ and IL-12 mRNAs in vaccinia virus infected U937 cells, while no change in IL-10 mRNA was found in virally infected cells (data not shown).

\section{Human endothelium exhibits early change in IL-6 production}

Vaccinia virus infected human umbilical vein endothelial cells exhibit increased levels of IL-6 mRNA at $2 \mathrm{~h}$ (Fig. 4A) and moderate IL-6 protein stimulation (statistically not significant) found at $6 \mathrm{~h}$ (Fig. 4B). Thus, the production of IL-6 in primary cultures of endothelial cells is stimulated by the virus earlier than in two other cell types. NF- $\kappa$ B early activation in $\mathrm{V}$-infected HUVEC (30 min-Fig. 5B) supports the latter observation. Vaccinia virus caused similar early increase in DNA binding activity in U937 cells (Fig. 5A).

\section{Discussion}

Proinflammatory cytokines play an important role in modulating the pathogenesis of viral infections.9,17 Pleiotropic cytokines, like TNF $\alpha$, IL-1 $\beta$ and IL-6, have been established as potent inducers of an inflammatory response with fever, acute phase protein synthesis in the liver and cofactors of $\mathrm{T}$ and $\mathrm{B}$ lymphocyte and macrophage activation. ${ }^{18}$ Little is known about the regulatory role played by the cytokines in vaccinia virus infection. Since genetically engineered poxviruses are widely used for recombinant gene expression and vaccination, ${ }^{19}$ therefore its pathogenesis in human tissues is of potencial interest. In this study, the capacity of three types of human cell lines to produce acute phase cytokines following vaccinia virus infection, was tested.

Fibroblasts, that do not classically belong to the immune system, produce IL-6 and IL-1 that can influence the local and systemic reactions observed during host defense against viral infections. Increased production of IL- 6 and IL-1 $\beta$ found in the infected cells in culture (Figs 1 and 2), suggests that the cytokines may play an important role in the pathogenesis of V. Excessive amounts of IL-1 $\beta$ produced by human skin fibroblasts during vaccinia virus infection could be bound with high affinity by the VV IL-1 $\beta$ 
(A)

Northern blotting:

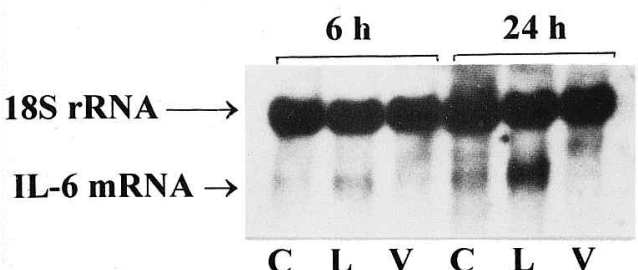

RT-PCR:
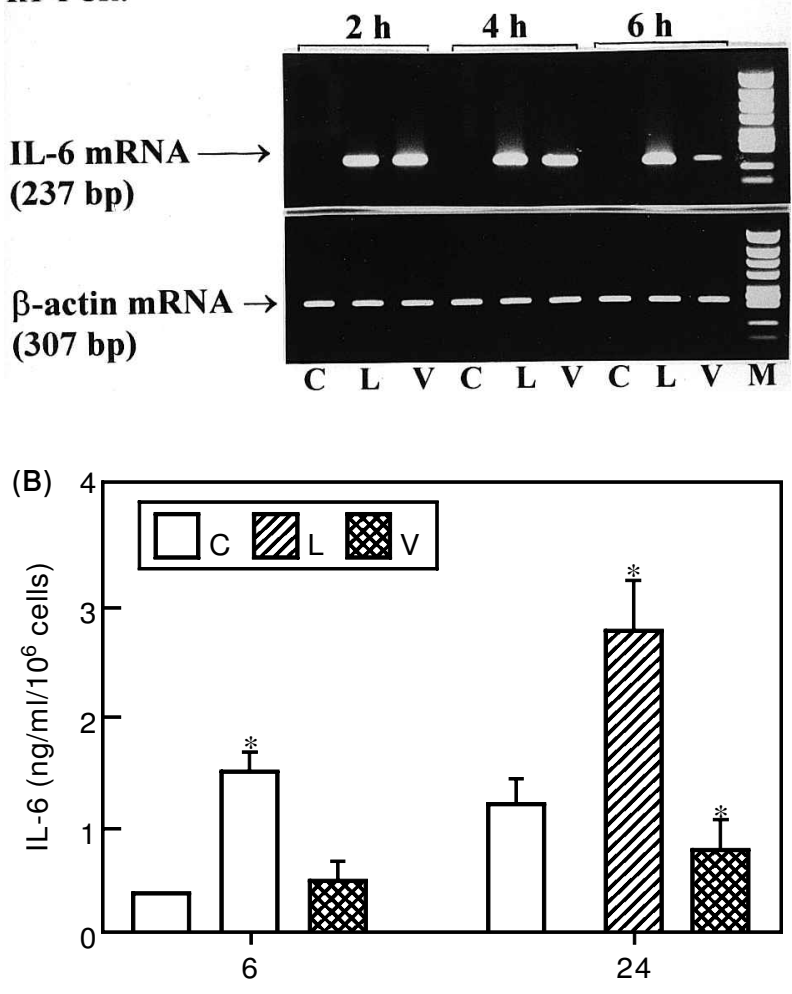

Hours p.i./p.s.

FIG. 4. Effect of vaccinia virus infection on IL-6 expression in human endothelial cells. IL-6 mRNA was measured for 6 and $24 \mathrm{~h}$ samples by hybridization with human cDNA probe giving also unspecific signal with $18 \mathrm{~S}$ rRNA. Additionally, 2 , 4 and $6 \mathrm{~h}$ RNA samples were analysed by RT-PCR (A). The cytokine protein was determined by ELISA in the culture media from three separate experiments and expressed in ng/ $\mathrm{ml}$ of medium and $10^{6}$ cells. Vaccinia virus infection was at $\mathrm{MOI} 2: 1$. LPS-stimulated cultures were used as the positive control. p.i.-post infection; p.s.-post stimulation. Results are expressed as the mean \pm standard deviation. Statistically significant results and $P$ values $<0.01$ are marked by* .

receptor encoded by gene $\mathrm{B} 15 \mathrm{R}$ in the Western Reserve (WR) strain. ${ }^{20}$ However, no mechanism for IL6 neutralization was found in vaccinia virus so far.

Amongst its pleiotropic effects, TNF $\alpha$ possesses a remarkable antiviral activity and the ability to kill virus-infected cells. ${ }^{21}$ On the other hand, a role for TNF in activation of human immunodeficiency virus replication was found. ${ }^{22}$ In our studies, vaccinia virus
(A)

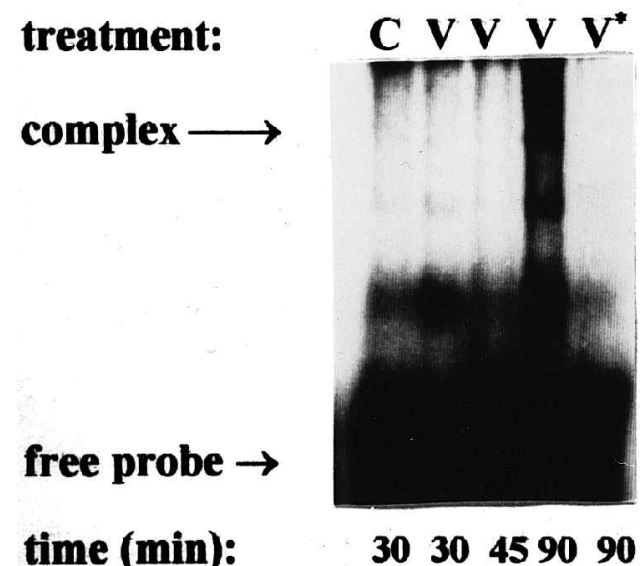

(B)

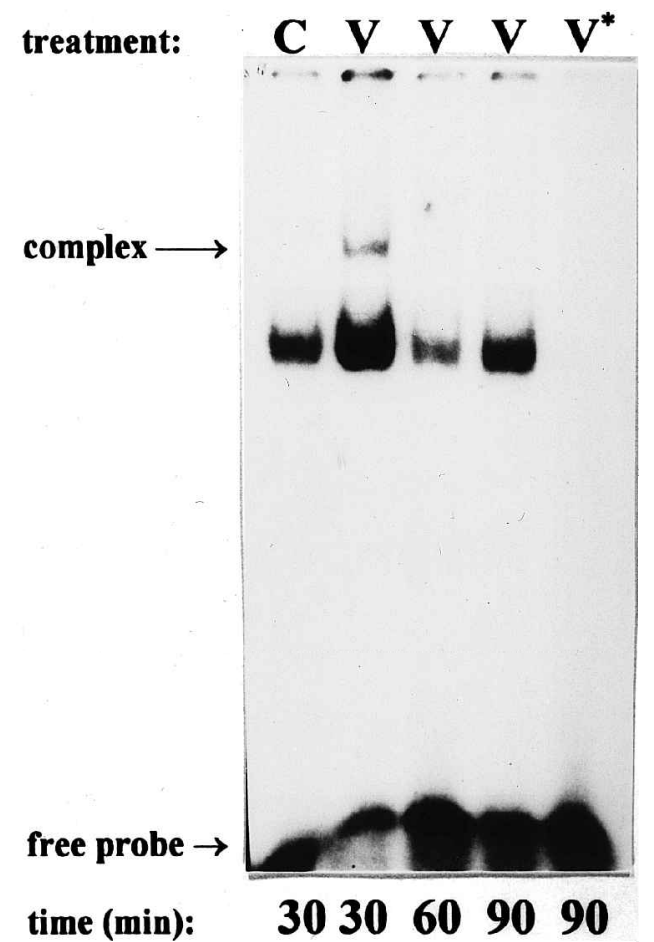

FIG. 5. Vaccinia virus inducible NF-кB binding activity in U937 and HUVEC. Double-stranded oligonucleotide comprising $\mathrm{NF}-\kappa \mathrm{B}$ site was incubated with nuclear extracts isolated from control (C) and vaccinia virus (V) infected U937 cells (MOI 1:1) (A) or HUVEC (MOI 2:1) (B). $V^{*}-100$-fold excess of unlabelled dsDNA oligonucleotide added as a competitor. Specific complexes and free probes are indicated.

induced profound increase in TNF $\alpha$ production only in the monocytic cell line U937 (Fig. 3A and B), whereas no detectable levels of the cytokine were found in fibroblasts and endothelial cells. Our results demonstrate that vaccinia virus induce TNF $\alpha$ transcriptionally, although translational control of TNF production was found by others. ${ }^{3}$ Cowpox virus encoded soluble TNF receptor ( $\mathrm{crmC}$ ) is able to 
inhibit host-elicited $\mathrm{TNF}^{23}$ The stimulatory effect of $\mathrm{VV}$ on the cytokine production places vaccinia virus in the group of other TNF $\alpha$ inducers. ${ }^{9,24}$ However, other viruses, e.g. EBV, inhibit TNF transcription. ${ }^{25}$

Three other cytokines were preliminary estimated in infected monocytes by RT-PCR: IL-12, IL-1 $\beta$ and IL10. IL-1 $\beta$ and IL-12 both act as proinflammatory cytokines and additionally IL-12 promotes Th1dependent resistance to infections by different agents. ${ }^{26}$ On the other hand, IL-10, known from its suppressing effect on cytokine production by HIVinfected macrophages and T cells, ${ }^{27}$ was not induced in U937 cells by VV at mRNA level (our unpublished data). Thus, vaccinia virus infection in monocytes seems to elicit mainly proinflammaroty cytokines, like, IL-1, TNF $\alpha$ and IL-12.

Endothelial cells play a key role in viral tropism in vivo as they are directly exposed to the circulating blood. Vaccinia virus infection of primary cultures of endothelial cells showed very early up-regulation of specific transcripts (at $2 \mathrm{~h}$ ) followed by an increase in IL-6 secretion at $6 \mathrm{~h}$ (Fig. 4), therefore it is suggested that endothelial cells are more susceptible to vaccinia virus infection than fibroblasts and monocytic cell line in which the effect of similar infectious doses of the virus was delayed.

Transcription factor NF- $\mathrm{B}$ is crucial in activating the transcription of genes encoding proinflammatory cytokines, therefore vaccinia virus induced IL-6 and $\mathrm{TNF} \alpha$ production can be in part explained by rapid increase in NF-KB-DNA binding activity found in U937 and HUVEC (Fig. 5), and this is the first report on WV effects on the transcription factor binding. ${ }^{6}$

Since this is in vitro study, it would be difficult to relate the results of our studies directly to vaccinia virus infection in vivo. When a virus induces moderate amounts of cytokines, it may be beneficial by eliciting an immediate antiviral response, but it may cause adverse effects when cytokine release is highly elevated by bacterial products (LPS). Our data (Fig. 2) suggest that the well-known severe manifestations of combined virus-bacterial infections ${ }^{28}$ may be due, at least in part, to an enhanced release of the endogenous pyrogens TNF $\alpha$ and IL-1 which both may lead upon introduction into circulation to an inflammatory response with high fever, shock syndromes, and tissue damage. ${ }^{29}$

\section{References}

1. Moss B. Poxviridae: the viruses and their replication. In: Fields BN, Knipe, DM, Howley PM, et al., eds. Fields Virology. Philadelphia: Lippincott-Raven Publishers, 1996; 2637-2671.

2. Moss B. Vaccinia virus transcription. In: Conaway RC, Conaway JW, eds Transcription: Mechanism and Regulation. New York: Raven Press, 1994; 185-205.

3. Willeaume V, Kruys V, Mijatovic T, Huez G. Tumor necrosis factor- $\alpha$ production induced by viruses and by lipopolysaccharides in macrophages: similarities and differences. J Inflammat 1996; 46: 1-12.
4. Carpenter EA, Ruby J, Ramshaw IA. IFN- $\gamma$, TNF, and IL-6 production by vaccinia virus immune spleen cells. J Immunol 1994; 152: 2652-2659.

5. Sedger L, Ramshaw I, Condie A, Medveczky J, Braithwaite A, Ruby J. Vaccinia virus replication is independent of cellular HSP72 expression which is induced during virus infection. Virology 1996; 225 423-427.

6. Muller JM, Ziegler-Heitbrock HWL, Baeuerle PA. Nuclear factor kappa B, a mediator of lipopolysaccharide effects. Immunobiology 1993; 187: 233-256.

7. Murayama T, Kuno K, Jisaki F, et al. Enhancement of human cytomegalovirus replication in a human lung fibroblast cell line by interleukin-8. $J$ Virol 1994; 68: 7582-7585.

8. Moore KW, O'Garra A, de Waal Malefyt R, Vieira P, Mosmann TR Interleukin 10. Annu Rev Immunol 1993; 11: 165-190.

9. Vilcek J, Sen GC. Interferons and other cytokines. In: Fields BN, Knipe DM, Howley PM, et al., eds. Fields Virology. Philadelphia: LippincottRaven Publishers, 1996; 375-399.

10. Smith GL Virus proteins that bind cytokines, chemokines or interferons. Curr Opin Immunol 1996; 8: 467-471.

11. Pickup DJ. Poxviral modifiers of cytokine responses to infection. Infectious Agents and Disease 1994; 3: 116-127.

12. Burleson FG, Chambers TM, Wiedbrauk DL. Introduction to quantal virus assays. In: Virology. A Laboratory Manual. London: Academic Press, 1991; 53-57.

13. Rose-John S, Dietrich A, Marks F Molecular cloning of mouse protein kinase C (PKC) cDNA from Swiss 3T3 fibroblasts. Gene 1988; 74 : 465-471.

14. Sambrook J, Fritsch EF, Maniatis T. Molecular Cloning: A Laboratory Manual. Cold Spring Harbor: Cold Spring Harbor Laboratory, 1989; 18.88 .

15. Suzuki YJ, Mizuno M, Packer L Signal transduction for nuclear factor- $\mathrm{B}$ activation. Proposed location of antioxidant-inhibitable step. J Imm unol 1994; 153: 5008-5015.

16. Duyao MP, Buckler AJ, Sonenshein GE Interaction of an NF-kB-like factor with a site upstream of the c-myc promoter. Proc Natl Acad Sci USA 1990; 87: 4727-4731.

17. Haagmans BL, Stals FS, Van der Meide PH, Bruggeman CA, Horzinek MC, Schijns VECJ. Tumor necrosis factor alpha promotes replication and pathogenecity of rat cytomegalovirus. J Virol 1994; 68: 2297-2304.

18. Koj A. Initiation of acute phase response and synthesis of cytokines. Biochim Biophys Acta 1996; 1317: 84-94.

19. Moss B. Genetically engineered poxviruses for recombinant gene expression, vaccination, and safety. Proc Natl Acad Sci USA 1996; 93: $11341-11348$.

20. Alcami A, Smith GL Cytokine receptors encoded by poxviruses: a lesson in cytokine biology. Immunol To day 1995; 16: 474-478.

21. Matsuyama T, Hamamoto Y, Soma G-I, Mizuno D, Yamamoto N, Kobayashi N. Cytocidal effect of tumor necrosis factor on cells chronically infected with human immunodeficiency virus (HIV): enhancement of HIV replication. J Virol 1989; 63: 2504-2509.

22. Rosenberg ZF, Fauci AS. Immunopathogenic mechanisms of HIV infection: cytokine induction of HIV expression. Immunol Today 1990; 11: 176-180.

23. Smith CA, Hu FQ, Smith TD, et al. Cowpox virus genome encodes a second soluble homologue of cellular TNF receptors, distinct from CrmB, that binds TNF but not LT alpha. Virology 1996; 223: 132-147.

24. Aderka D, Holtman H, Toker L, Hahn T, Wallach D. Tumor necrosis factor induction by Sendai virus. J Im munol 1986; 136: 2938-2942.

25. Gosselin J, Menezes J, D’Addario M, et al. Inhibition of tumor necrosis factor- $\alpha$ transcription by Epstein-Barr virus. Eur J Immunol 1991; 21: 203-208.

26. Trinchieri G. Cytokines acting on or secreted by macrophages during intracellular infection (II-10, IL-12, IFN-gamma). Curr Opin Immunol 1997; 9: 17-23.

27. We issman D, Poli G, Fauci AS. Interleukin 10 blocks HIV replication in macrophages by inhibiting the autocrine Loop of tumor necrosis factor alpha and interleukin 6 induction of virus. AIDS Res Human Retrovir 1994; 10: 1199-1206.

28. Esser R, Glienke W, von Briesen H, Rubsamen-Waigmann H, Andreesen R Differential regulation of proinflammatory and hematopoietic cytokines in human macrophages after infection with human immunodeficiency virus. Blood 1996; 88: 3474-3481.

29. Beutler B, CeramiA. The biology of cachectin/TNF a primary mediator of the host response. Annu Rev Immunol 1989; 7: 625-655.

ACKNOWLEDGEMENTS. This work was supported by grant 6-P203-01607 from the Committee of Scientific Research (KBN, Warsaw, Poland). We thank Dr A. Guzdek for her help in cytokine determination.

Received 7 November 1997; accepted in revised form 11 January 1998 


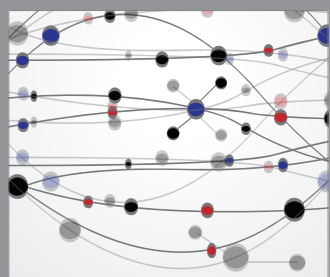

The Scientific World Journal
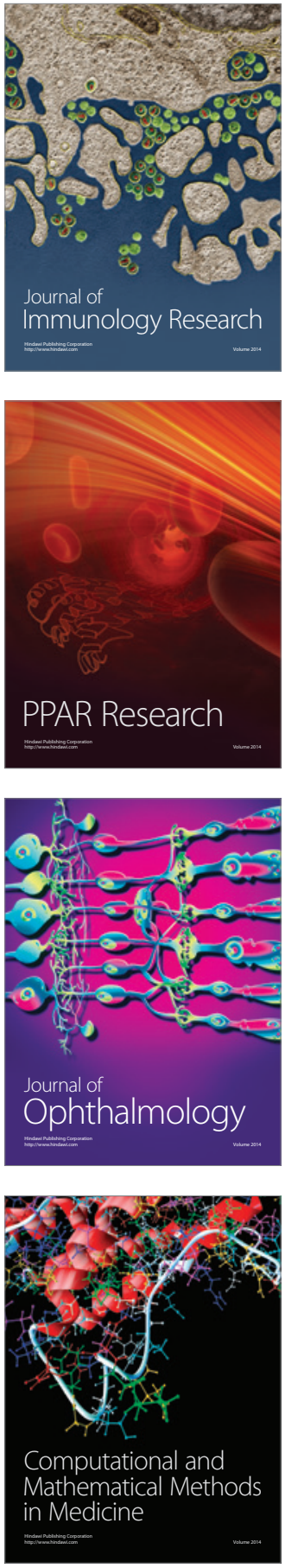

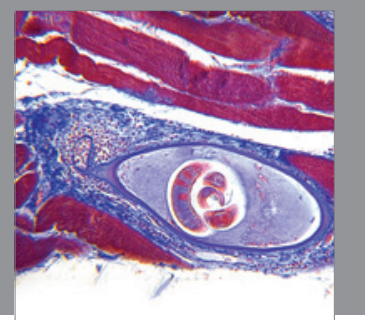

Gastroenterology

Research and Practice
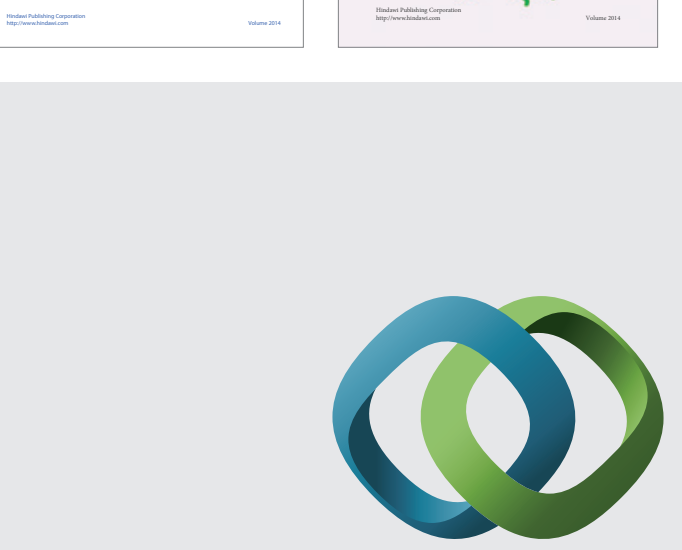

\section{Hindawi}

Submit your manuscripts at

http://www.hindawi.com
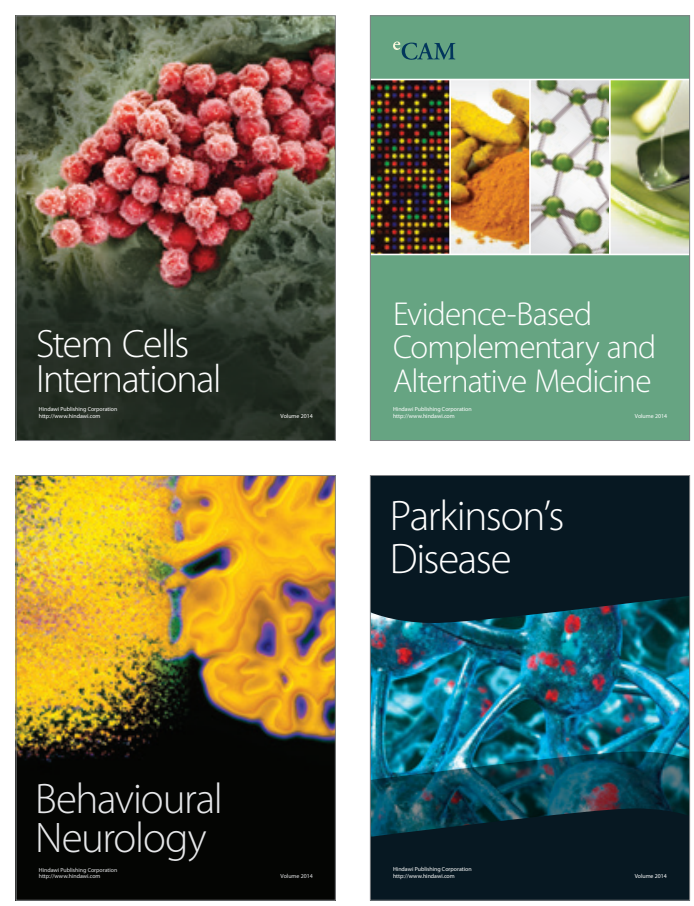

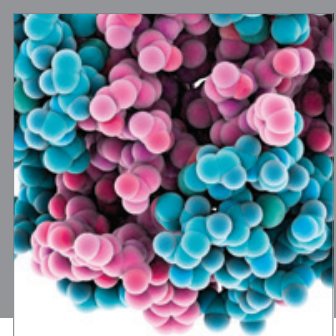

Journal of
Diabetes Research

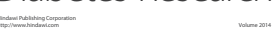

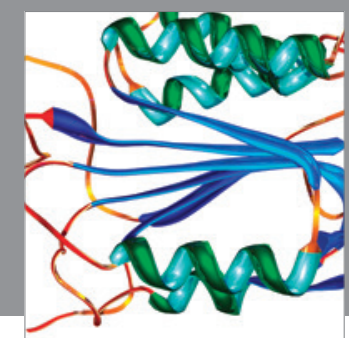

Disease Markers
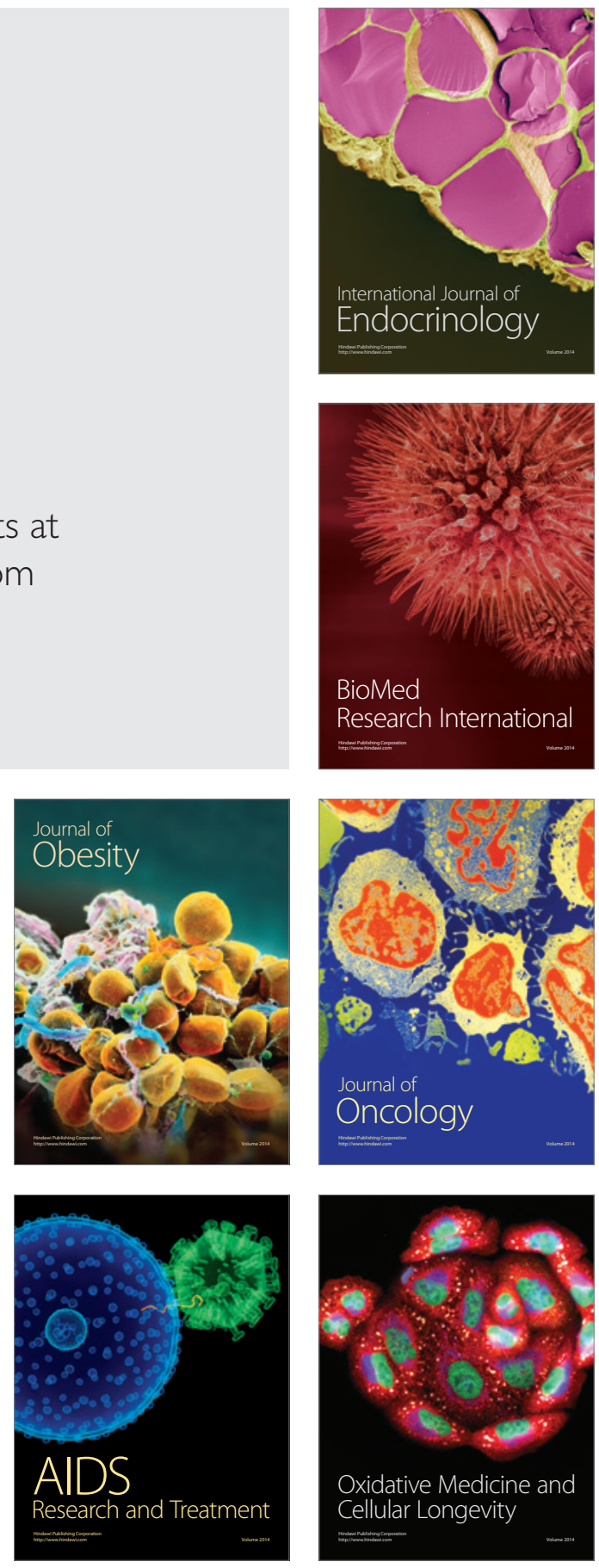